\title{
Corrigendum: From genes to protein mechanics on a chip
}

Marcus Otten, Wolfgang Ott, Markus A Jobst, Lukas F Milles, Tobias Verdorfer, Diana A Pippig, Michael A Nash \& Hermann E Gaub Nat. Methods 11, 1127-1130 (2014); published online 7 September 2014; corrected after print 5 November 2014

In the version of this article initially published, the grant "European Research Council Grant Cellufuel (Advanced Grant 294438)" was mistakenly left out of the Acknowledgements. The error has been corrected in the HTML and PDF versions of the article.

\section{Erratum: 0nco-proteogenomics: cancer proteomics joins forces with genomics}

Javier A Alfaro, Ankit Sinha, Thomas Kislinger \& Paul C Boutros

Nat. Methods 11, 1107-1113 (2014); published online 30 October 2014; corrected after print 5 November 2014

In the version of this article initially published, page numbers were missing from reference number 30 . The error has been corrected in the HTML and PDF versions of the article.

\section{Erratum: Light microscopy with lattices}

Nina Vogt

Nat. Methods 11, 1191 (2014); published online 25 November 2014; corrected after print 10 December 2014

In the version of this article initially published, the resolution obtainable with lattice light-sheet microscopy was erroneously stated as about 100 micrometers. The correct value is 100 nanometers. The error has been corrected in the HTML and PDF versions of the article.

\section{Corrigendum: Mining the 0 -glycoproteome using zinc-finger nuclease-glycoengineered SimpleCell lines}

Catharina Steentoft, Sergey Y Vakhrushev, Malene B Vester-Christensen, Katrine T-B G Schjoldager, Yun Kong, Eric Paul Bennett, Ulla Mandel, Hans Wandall, Steven B Levery \& Henrik Clausen

Nat. Methods 8, 977-982 (2011); published online 9 October 2011; corrected after print 8 January 2015

In the version of this article initially published, the T3M4 cell line used for the experiments was mislabeled as Capan-1. The error has been corrected in the HTML and PDF versions of the article.

\section{Corrigendum: Time-resolved crystallography using the Hadamard transform}

Briony A Yorke, Godfrey S Beddard, Robin L Owen \& Arwen R Pearson

Nat. Methods 11, 1131-1134 (2014); published online 5 October 2014; corrected after print 8 January 2015

In the version of this article initially published, the Figure 2 legend misidentified the control data as on the left and the HATRX data as on the right. The error has been corrected in the HTML and PDF versions of the article. 